\title{
Small-Scale Die-Offs in Woodrats Support Long-Term Maintenance of Plague in the U.S. Southwest
}

\author{
Michael Kosoy, Pamela Reynolds, ${ }^{2}$ Ying Bai,, Kelly Sheff, ${ }^{1}$ Russell E. Enscore, \\ John Montenieri, Paul Ettestad, and Kenneth Gage ${ }^{1}$
}

\begin{abstract}
Our longitudinal study of plague dynamics was conducted in north-central New Mexico to identify which species in the community were infected with plague, to determine the spatial and temporal patterns of the dynamics of plague epizootics, and to describe the dynamics of Yersinia pestis infection within individual hosts. A total of 3156 fleas collected from 535 small mammals of 8 species were tested for $Y$. pestis DNA. Nine fleas collected from six southern plains woodrats (Neotoma micropus) and from one rock squirrel (Otospermophilus variegatus) were positive for the pla gene of $Y$. pestis. None of 127 fleas collected from 17 woodrat nests was positive. Hemagglutinating antibodies to the $Y$. pestis-specific F1 antigen were detected in 11 rodents of 6 species. All parts of the investigated area were subjected to local disappearance of woodrats. Despite the active die-offs, some woodrats always were present within the relatively limited endemic territory and apparently were never exposed to plague. Our observations suggest that small-scale die-offs in woodrats can support maintenance of plague in the active U.S. Southwestern focus.
\end{abstract}

Keywords: epizootics, plague, woodrats

\section{Introduction}

$\mathbf{U}$ NDERSTANDING THE EPIDEMIOLOGY of plague requires knowledge of the natural history of this rodent- and fleaassociated zoonosis. Despite a long history of field-based investigations of plague in many parts of the U.S. Southwest and Pacific Coast, some very fundamental questions remain on the ecology of Yersinia pestis in its natural reservoirs, specifically, discussions about the continuity of the plague maintenance cycle in nature, a topic that has remained largely hypothetical. Relatively few studies have investigated the course of plague infection in individual rodent hosts over multiyear periods. The limitation of such studies makes it difficult to suggest ways for proving or rejecting hypotheses pertaining to resistance of some rodent individuals to plague (Brinkerhoff et al. 2010, Friggens et al. 2010).

It is widely accepted that plague enzootic cycles occur within wild rodent populations, from which epizootics arise of varying duration and extent, and, therefore, are of varying risk to humans. The enzootic hosts of plague are believed by many to be rodent species that are moderately resistant to $Y$. pestis or have some specific biological characteristics that prevent a complete elimination of the infection from their populations. This concept was originally proposed by scientists working in endemic areas of Asia and remains relevant today (Fenyuk 1940, Rall 1965, Gage and Kosoy 2005).

Some American researchers, including those who initiated field investigations of plague in California during the 1960s, shared this view and reported some data that directly or indirectly support such a concept. For instance, occasional observations indicated that individual voles (Microtus ssp.) and mice (Peromyscus ssp.) can survive plague epizootics based on repeated captures of seropositive animals and thus presumably play a crucial role in the maintenance of this infection by continuing to produce offspring, some of which will be susceptible and develop sufficiently high bacteremias to infect fleas before succumbing to infection. According to this concept, plague occasionally spills over to other much more susceptible hosts (epizootic hosts) that often die in rapidly spreading epizootics that infect large numbers of fleas and also pose threats to humans and other mammals (Goldenberg et al. 1964, Kartman et al. 1964, Poland and Barnes 1979, Lang and Wills 1991).

Later, Davis et al. (2002) provided evidence of plague circulation in populations of Merriam's chipmunks (Tamias

\footnotetext{
${ }^{1}$ Division of Vector-Borne Diseases, Centers for Disease Control and Prevention, Fort Collins, Colorado.

${ }^{2}$ New Mexico Department of Health, Santa Fe, New Mexico.

(C) Michael Kosoy et al. 2017; Published by Mary Ann Liebert, Inc. This is an Open Access article distributed under the terms of the Creative Commons Attribution License, which permits unrestricted use, distribution, and reproduction in any medium, provided the original work is properly cited.
} 
merriami) and dusky-footed woodrats (Neotoma fuscipes) in Ventura County, California. Observations of $Y$. pestis-specific antibodies in healthy appearing rodents or previously bacteremic animals provide some interesting points for the discussion; however, this is not ultimate evidence that survivors of infection with these bacteria, demonstrated by the presence of antibodies, indeed contribute to long-term persistence of plague (Salkeld and Stapp 2008). Other contributing scenarios may include long-term infection of vector-competent flea species or dispersal of fleas (and $Y$. pestis) among different rodent genera or rodent metapopulations in geographically overlapping distribution ranges (Gage and Kosoy 2005).

In this study, we wished to evaluate this and other mechanisms that could be responsible for maintaining plague in a specific system, including the idea that plague is maintained by low transmission rates and low mortality rates among highly susceptible hosts. We focused our efforts on a relatively small site in north-central New Mexico, which lies within a region that has been well known since the mid-1960s as one of two areas in the United States (Southwest and Pacific Coast plague foci) with relatively high levels of human and animal plague (Poland et al. 1979). Available reports demonstrated evidence of circulation of $Y$. pestis among local animal populations in the area within or in close proximity to the study area. Starting from 1988, when the first human plague case was reported in this area, plague activity was documented in 15 of 18 following years (plague activity was not reported in 1989, 1990, and 1994).

The reports of plague activity from New Mexico Department of Health included findings of $Y$. pestis bacterium or $Y$. pestis antibodies in humans, animals, and fleas. Human cases were reported in July 2001 (one case) and in November 2002 (two cases) (Perlman et al. 2003, Colman et al. 2009). Animal surveillance during the period of 1995-1997 resulted in identification of $Y$. pestis in two cats, one dog, seven woodrats, and three fleas (one from a deer mouse and two from woodrats). These epidemiological data presumptively supported a substantial role of woodrats in maintenance of plague in this area (Colman et al. 2009).

Our goals were to collect a sufficient amount of data on the distribution of infected or previously infected animals within the study area, and to observe noticeable differences between this particularly persistent plague system and enzootic areas where intensity of the disease was much lower or the circulation of $Y$. pestis was observed only occasionally. The criteria for selection of the study sites included the following: (1) previous reports of plague activities such as human cases, laboratory-confirmed deaths in small mammals, laboratoryconfirmed infection of rodent fleas, or demonstrated specific antibodies in small mammals or carnivores in this area; (2) high and stable density of rodents based on previous observations; (3) potential for rodent-human interactions; and (4) relatively easy access of a vehicle, permitting public acceptance for conducting the long-term and mark-release animal studies. The study was planned and conducted in close collaboration with the New Mexico Department of Health.

The study design included a mark-release-recapture platform and provided the following types of data and estimates of parameters: (1) temporal and spatial dynamics of rodent host population; (2) interrelationships between dynamics of rodent hosts and their fleas; (3) territorial movement of individually marked rodents and their association with specific burrows; (4) detection of antibodies to $Y$. pestis among rodents; (5) presence of $Y$. pestis DNA in fleas collected from rodents and selected rodent nests; (6) bacteriological investigation of rodent carcasses found during epizootics; and (7) spatial proximity between observed rodent die-offs and laboratory-confirmed $Y$. pestis evidence within the rodent community. A specific emphasis was placed on investigation of two species of woodrats (Neotoma micropus and N. albigula), the most common rodent species in this area and primary suspects as sources of human plague in this area based on preliminary observations.

\section{Materials and Methods}

\section{Study sites}

The longitudinal study of plague dynamics was conducted within a residential subdivision in Santa Fe County, located in north-central New Mexico with an elevation of 2000 meters. Two study sites were selected approximately one mile from each other. Overall, the sites are ecologically similar and typical for a pinyon-juniper ecosystem within a suburban area. Differences between the sites were mostly in terms of the anthropogenic modification of the environment. Study site 1 was located in close proximity to residential houses, on largesized lots, with a significant human-wildlife interface, while study site 2 contained no man-made structures and was primarily used as a recreational hiking area for local residents.

\section{Rodent trapping}

Trapping of rodents was conducted year round for three consecutive nights per month, consisting of 36 trapping sessions between November 2002 and August 2005. Animals were captured at the 89 trap stations (TS): 64 in site 1 and 25 in site 2 . The same TS were used in all consecutive trapping sessions except TS 41-60 within the site 1 that were added to the study starting June 2003. TS were selected by visual identification of a freshly occupied woodrat den within both sites. Global Positioning System coordinates were collected for each TS and clearly mapped to geographically identify the collection point for each captured rodent. During each trapping episode, the status of woodrat burrows in terms of animal occupancy and activity was recorded by trapping success, presence of fresh feces, freshly disturbed soil, and absence of spider webs.

Rodents were live-trapped using a combination of three traps of different sizes that were placed at each TS: (1) a small Sherman trap $\left(2 \times 2.5 \times 6.5^{\prime \prime}\right)$ targeting mice-size rodents $(\mathrm{HB}$ Sherman Trap Company, Tallahassee, FL); (2) a large Sherman trap $\left(3 \times 3.5 \times 9^{\prime \prime}\right)$ targeting rat-size rodents $(\mathrm{HB}$ Sherman Trap Company); and (3) a Tomahawk trap $\left(4 \times 4 \times 10^{\prime \prime}\right)$ targeting squirrel-size rodents and rabbits (Tomahawk Live Trap Company, Hazelhurst, WI). Traps were baited with a mixture of oats and peanut butter, set in the afternoon and checked the following morning and afternoon. Cotton balls were placed in each trap during cold weather to reduce the potential for hypothermia. All traps with rodents were collected in individual plastic bags and brought to the nearby processing site.

\section{Processing rodents}

Rodents were anesthetized in a chamber with a mixture of isoflurane inhalation anesthetic (Halocarbon Products Corporation, Peachtree Corners, GA) and oxygen. The Isoflurane 
mixture was delivered to the chamber through a nonrebreathing portable vaporizer (Seven Seven Anesthesia, Fort Collins, CO). Animals were either removed from the larger traps before placing a face mask for anesthesia on their heads or, if sufficiently small, the entire trap was placed into the induction chamber (modified tool box with a transparent plastic window). When an anesthetized animal lost its coordination, it was removed from the induction chamber and the face mask was placed on the animal's nose to maintain proper anesthetic exposure.

Blood was collected by retro-orbital bleed using heparinized microhematocrit capillary tubes coated with ethylenediaminetetraacetic acid (MWI Veterinary Supply Co., Denver, CO). Nobuto filter paper strips (Toyo Roshi Kaisha Ltd., Tokyo, Japan) with a 5- by 30-mm section for adsorption of $0.1 \mathrm{~mL}$ of whole blood were also used for serological analysis. In the event of an occasional death of an animal in a trap or during a procedure, spleen and liver samples were aseptically collected for culturing and immunofluorescence testing. All samples were quickly placed on dry ice and held until being returned to the laboratory where samples were stored at $-80^{\circ} \mathrm{C}$ until tested. Species and sex identification, reproductive status, body measurements, and weight were recorded for each animal. Captured animals were marked individually by ear-tag or/and subcutaneous transponder (AVID, Folsom, LA) and were released at the location of capture. Animal handling procedures were approved by CDC's Division of Vector-Borne Diseases Institutional Animal Care and Use Committee (protocol number 06-008).

\section{Flea collection}

The rodents were thoroughly combed over a metal pan and ectoparasites were collected in one tube per animal and placed on dry ice until arrival at the CDC laboratory where they were stored at $-80^{\circ} \mathrm{C}$ until identified and tested. In addition to fleas collected from small mammals, fleas were collected from 20 woodrat nests within the area 2 at the end of the study. The dens were partially or fully dissembled to find nest material and the associated burrows were swabbed using a piece of white flannel cloth attached to the end of a steel cable (plumber's snake). The nest material and the cloth were placed separately into plastic bags for later flea recovery.

Fleas were identified to species and sex using published taxonomic keys (Hubbard 1947, Stark 1970, Hopkins and Rothschild 1971, Furman and Catts 1982). Fleas were evaluated for the presence of a fresh blood meal (visual observation of blood in the digestive tract) using a dissecting microscope (Olympus SZ-11, Center Valley, PA).

\section{Serology}

Plague serological analysis was conducted by using a passive hemagglutination (PHA) assay, which is based on detection of antibodies against the capsule antigen (F1) specific to $Y$. pestis (Chu 2000). The antibodies were eluted from dried Nobuto strips overnight into a sodium borate buffer solution. Twenty-five microliter of the eluent was used for the agglutination test. Because of possible nonspecific cross-reactivity, all PHA-positive samples were further tested with a passive inhibition (PHI) test. Final endpoint titers were determined by subtracting the PHI wells showing agglutination from the last PHA well showing full agglutination.

\section{Bacteriological analysis}

Blood samples from live animals and triturated tissues from dead animals were plated on agar with sheep blood and incubated at $28^{\circ} \mathrm{C}$ for $48 \mathrm{~h}$ to recover $Y$. pestis, if present. The plates were examined for characteristic colonies after 24 and $48 \mathrm{~h}$. The bacteriophage lysis test was performed on a pure culture to confirm the presence of the plague bacilli using a plague bacteriophage-impregnated filter paper strip (Chu 2000). Tissue samples (spleen and liver) from dead animals were also tested for plague by direct fluorescent antibody (DFA) assay using polyclonal rabbit anti-F1 serum tagged with fluorescein isothiocyanate (Chu 2000). Antigen-positive samples were further tested by mouse inoculation to determine whether viable $Y$. pestis was present.

\section{Detection of $\mathrm{Y}$. pestis DNA in fleas}

All fleas were individually analyzed for $Y$. pestis. Fleas were triturated in sterile tubes containing $200 \mu \mathrm{L}$ of sterile brain-heart infusion broth and $3 \mathrm{~mm}$ sterile glass beads in a mixer mill (Retsch MM300, Newton, PA) at 20 bps for $8-$ $10 \mathrm{~min}$. The triturate was then placed in a heat block and boiled at $95^{\circ} \mathrm{C}$ for $10 \mathrm{~min}$ to heat extract the DNA. After trituration, $2.5 \mu \mathrm{L}$ of the flea suspension was used for polymerase chain reaction (PCR) testing. The PCR primers were Yp1 (5'-ATCTTACTTTCCGTGAGAAG-3') and Yp2 (5'CTTGGATGTTGAGCTTCCTA-3'), which targeted a 478bp fragment of the pla gene and PCR procedures followed Stevenson et al. (2003).

\section{Results}

\section{Rodent community}

Overall, 1194 individual small mammals were captured during the study period. Captured rodents belonged to 10 genera representing 14 species: the Ord's kangaroo rat (Dipodomys ordii), the banner-tailed kangaroo rat (Dipodomys spectabilis), the house mouse (Mus musculus), the whitethroated woodrat ( $N$. albigula), the southern plains woodrat (N. micropus), the northern grasshopper mouse (Onychomys leucogaster), the rock squirrel (Otospermophilus variegatus), the silky pocket mouse (Perognathus flavus), the whitefooted mouse (Peromyscus leucopus), the deer mouse (Peromyscus maniculatus), the pinyon mouse (Peromyscus truei), the western harvest mouse (Reithrodontomys megalotis), the hispid cotton rat (Sigmodon hispidus), and the spotted ground squirrel (Xerospermophilus spilosoma). Besides rodents, one species of lagomorph, the desert cottontail (Sylvilagus audubonii), was captured.

\section{Animal recaptures}

In addition, 604 recaptures were documented. Each captured animal was sampled, including recaptures, producing a total of 1798 animals sampled. The most prevalent rodent species was $N$. micropus (419 individual animals and 817 captures); less prevalent, but common were $N$. albigula (81 and 168), D. ordii (315 and 387), P. leucopus (120 and 128), and $S$. variegatus (84 and 102) (Table 1).

Of the rodents captured during the study, 270 were collected more than once. Most of recaptured animals belonged to $N$. micropus (151), N. albigula (29), D. ordii (54), and $O$. 
Table 1. Captured and Recaptured ANIMALS By SPECIES

\begin{tabular}{|c|c|c|c|}
\hline Species & Individuals & $\begin{array}{c}\text { Captured } \\
\text { animals }\end{array}$ & $\begin{array}{c}\text { Recaptured } \\
\text { animals }\end{array}$ \\
\hline Dipodomys ordii & 315 & 387 & 54 \\
\hline Dipodomys spectabilis & 6 & 13 & 4 \\
\hline Mus musculus & 3 & 3 & 0 \\
\hline Neotoma albigula & 81 & 168 & 29 \\
\hline Neotoma micropus & 419 & 817 & 151 \\
\hline Onychomys leucogaster & 23 & 24 & 1 \\
\hline $\begin{array}{l}\text { Otospermophilus } \\
\text { variegatus }\end{array}$ & 84 & 102 & 14 \\
\hline Perognathus flavus & 4 & 4 & 0 \\
\hline Peromyscus leucopus & 120 & 128 & 8 \\
\hline $\begin{array}{l}\text { Peromyscus } \\
\quad \text { maniculatus }\end{array}$ & 42 & 43 & 1 \\
\hline Peromyscus truei & 12 & 15 & 0 \\
\hline $\begin{array}{l}\text { Reithrodontomys } \\
\text { megalotis }\end{array}$ & 8 & 8 & 0 \\
\hline Sigmodon hispidus & 1 & 1 & 0 \\
\hline Sylvilagus audubonii & 25 & 25 & 0 \\
\hline $\begin{array}{l}\text { Xerospermophilus } \\
\text { spilosoma }\end{array}$ & 51 & 60 & 8 \\
\hline Total & 1194 & 1798 & 270 \\
\hline
\end{tabular}

variegatus (14). Total number of samples collected from recaptured animals, including the first sample, was 851 . The number of samples collected from individual animals varied from 1 to 19 . Thirty-one individual woodrats (Neotoma) were captured and sampled more than five times.

\section{Woodrat populations}

Woodrats of two species (N. albugula and N. micropus) comprised $41 \%$ of small mammals captured in this area (490/ 1194). The dominance of woodrats in the rodent community varied by year (44-59\%) and season (55-80\%), but woodrats remained prominent during the entire period of the study. The demography of woodrats within the study area was previously published (Morway et al. 2008).

\section{Fleas on mammals}

Of 1147 live-captured small mammals (including recaptures), which were carefully checked for ectoparasites, fleas were found on $535(46.6 \%)$ animals. The level of flea infestation varied significantly between observed mammalian species (Table 2). The highest rate was recorded for $O$. variegatus $(57 / 75 ; 76.0 \%)$ and $S$. audubonii $(17 / 22 ; 72.3 \%)$. The woodrat species ( $N$. albigula and $N$. micropus), the most prevalent species of the rodent community, also had a high rate of flea infestation (combined 414/668; 62\%). Fleas were found on only $7.0 \%$ of mice of the genus Peromyscus. Rodents of some species (M. musculus, P. flavus, and R. megalotis) were free from fleas, which is not unusual for these species, although the number of these mice captured was low.

Nineteen species of fleas were identified among those collected from small mammals (Table 3). The largest numbers of fleas belonged to three species: Orchopeas sexdentatus (1195) and $O$. neotomae (311), both species typical for woodrats, and Oropsylla montana on rock squirrels. Overall, most mammals were infested with typical fleas specific for that host. Considering prevalence, $O$. sexdentatus $(68.4 \%)$ and $O$. neotomae $(18.5 \%)$ had the highest rates on woodrats collectively (N. albigula and N. micropus).

Two additional flea species were found on woodrats less frequently: Anomiopsyllus nudatus (5.3\%) and Megarthroglossus divisus (3.8\%). Besides O. montana, which was the most prevalent flea on rock squirrels (72.0\%), another flea species Hoplopsyllus anomalus was common (24.3\%) and in July 2003 , it was more prevalent than $O$. montana (68.4\% vs. $31.0 \%)$. In addition, fleas collected from rock squirrels contained 33 (3.6\%) Echidnophaga gallinaceae. Some fleas found on rock squirrels were likely acquired from other rodent species, for example, O. sexdentatus (1), a woodrat flea, and Meringis dipodomys (1), a kangaroo rat flea.

Three flea species of the genus Meringis (M. arachis, $M$. dipodomys, and $M$. parkeri) were most common on kangaroo rats (D. ordii and D. spectabilis)-79/95 (83.2\%). Besides fleas considered specific for these rodents, a few nonspecific fleas were found on kangaroo rats, including the woodrat fleas $O$. sexdentatus (1) and $O$. neotomae (1) and the rock squirrel flea $O$. montana (1).

Table 2. The Level of Flea Infestation by Mammalian Species and Season (Infested/Checked)

\begin{tabular}{|c|c|c|c|c|c|}
\hline Species & $\begin{array}{l}\text { Total (\% for } \\
>10 \text { animals) }\end{array}$ & $\begin{array}{l}\text { January- } \\
\text { March }\end{array}$ & $\begin{array}{c}\text { April- } \\
\text { June }\end{array}$ & $\begin{array}{c}\text { July- } \\
\text { September }\end{array}$ & $\begin{array}{l}\text { October- } \\
\text { December }\end{array}$ \\
\hline Dipodomys ordii & $21 / 165(12.7)$ & $1 / 1$ & $2 / 97$ & $7 / 43$ & $11 / 24$ \\
\hline Dipodomys spectabilis & $3 / 3$ & $1 / 1$ & $2 / 2$ & $0 / 0$ & $0 / 0$ \\
\hline Mus musculus & $0 / 2$ & $0 / 0$ & $0 / 2$ & $0 / 0$ & $0 / 0$ \\
\hline Neotoma albigula & $77 / 168(45.8)$ & $3 / 6$ & $40 / 93$ & $16 / 35$ & $18 / 34$ \\
\hline Neotoma micropus & $337 / 500(67.4)$ & $42 / 63$ & $179 / 258$ & $68 / 106$ & $48 / 73$ \\
\hline Onychomys leucogaster & $9 / 19(47.4)$ & $2 / 3$ & $2 / 3$ & $5 / 11$ & $0 / 2$ \\
\hline Otospermophilus variegatus & $57 / 75(76.0)$ & $2 / 2$ & $32 / 44$ & $15 / 19$ & $8 / 10$ \\
\hline Perognathus flavus & $0 / 4$ & $0 / 0$ & $0 / 1$ & $0 / 3$ & $0 / 0$ \\
\hline Peromyscus leucopus & $3 / 100(3.0)$ & $0 / 5$ & $1 / 81$ & $1 / 6$ & $1 / 8$ \\
\hline Peromyscus maniculatus & $5 / 43(11.6)$ & $1 / 10$ & $2 / 25$ & $0 / 1$ & $2 / 7$ \\
\hline Peromyscus truei & $3 / 15(20.0)$ & $1 / 1$ & $1 / 11$ & $0 / 2$ & $1 / 1$ \\
\hline Reithrodontomys megalotis & $0 / 5$ & $0 / 0$ & $0 / 4$ & $0 / 1$ & $0 / 0$ \\
\hline Sigmodon hispidus & $1 / 1$ & $0 / 0$ & $1 / 1$ & $0 / 0$ & $0 / 0$ \\
\hline Sylvilagus audubonii & $17 / 22(77.3)$ & $0 / 0$ & $9 / 13$ & $3 / 3$ & $5 / 6$ \\
\hline Xerospermophilus spilosoma & $2 / 25(8.0)$ & $0 / 0$ & $2 / 17$ & $0 / 8$ & $0 / 0$ \\
\hline Total & $535 / 1147$ & $53 / 92$ & $273 / 652$ & $115 / 238$ & $94 / 165$ \\
\hline
\end{tabular}


Table 3. Fleas Collected from Small Mammals

\begin{tabular}{|c|c|c|c|c|c|c|c|c|c|c|}
\hline Year & 2002 & 2003 & 2003 & 2003 & 2003 & 2004 & 2004 & 2004 & 2005 & \\
\hline Months & $\begin{array}{c}\text { November- } \\
\text { December }\end{array}$ & $\begin{array}{l}\text { January- } \\
\text { March }\end{array}$ & $\begin{array}{c}\text { April- } \\
\text { June }\end{array}$ & $\begin{array}{c}\text { July- } \\
\text { September }\end{array}$ & $\begin{array}{l}\text { October- } \\
\text { December }\end{array}$ & $\begin{array}{c}\text { January- } \\
\text { March }\end{array}$ & $\begin{array}{l}\text { April- } \\
\text { June }\end{array}$ & $\begin{array}{c}\text { July- } \\
\text { September }\end{array}$ & $\begin{array}{c}\text { April- } \\
\text { June }\end{array}$ & Total \\
\hline No. rodents & 73 & 60 & 232 & 130 & 127 & 26 & 197 & 107 & 227 & 1179 \\
\hline Aetheca wagneri & & & & 1 & & & & 1 & & \\
\hline Anomiopsyllus nudatus & 2 & 3 & 42 & 1 & 10 & & 7 & 2 & 15 & 82 \\
\hline Cediopsylla inaequalis & & & 25 & 8 & 17 & & 162 & & & 212 \\
\hline Echidnophaga gallinacea & & & 2 & 15 & 7 & & 1 & 16 & 1 & 42 \\
\hline Epitidea wemmani & & & & 1 & & & & & & \\
\hline Euhoplopsyllus glacialis & & & 5 & 18 & 45 & & 1 & & & 69 \\
\hline Hoplopsyllus anomalus & & & 40 & 145 & 3 & & 28 & 4 & 5 & 225 \\
\hline Malaraeus sinomиs & & & & 2 & 3 & & & & & \\
\hline Megarthroglossus divisus & 7 & 2 & & & 53 & 3 & 1 & 7 & & 73 \\
\hline $\begin{array}{l}\text { Meringis arachis } \\
\text { Meringis dipodomys }\end{array}$ & & & 44 & & & & & & 1 & 10 \\
\hline $\begin{array}{l}\text { Meringls alpoaomys } \\
\text { Meringis parkeri }\end{array}$ & & 10 & & 2 & 22 & 2 & 1 & 5 & & 10 \\
\hline Orchopeas leucopus & & 1 & 8 & 4 & 2 & 1 & 1 & & 1 & 18 \\
\hline Orchopeas neotomae & 12 & 20 & 85 & 13 & 27 & 1 & 38 & 17 & 98 & 311 \\
\hline Orchopeas sexdentatus & 59 & 100 & 500 & 205 & 45 & 9 & 56 & 44 & 177 & 1195 \\
\hline Oropsylla montana & 5 & 27 & 232 & 76 & 32 & & 215 & 4 & 85 & 676 \\
\hline $\begin{array}{c}\text { Peromyscopsylla } \\
\text { hesperomys }\end{array}$ & & & 1 & & 2 & & & & 5 & \\
\hline $\begin{array}{l}\text { Pleochaetis exilis } \\
\text { Thrassis bacchi }\end{array}$ & 2 & 2 & 2 & 5 & 2 & 6 & 3 & 2 & & 20 \\
\hline Total fleas & 87 & 165 & 986 & 496 & 270 & 22 & 514 & 102 & 387 & 3029 \\
\hline
\end{tabular}

The number of fleas collected from mice belonging to the genus Peromyscus (P. leucopus, P. maniculatus, and P. truei) was low-only 16 fleas were found on 158 mice. These included: Peromyscopsylla hesperomys (8), Orchopeas leucopus (3), Megarthroglossus divisus (2), Anomiopsyllus nudatus (1), and $O$. sexdentatus (2) - the last two are typically woodrat fleas, but are occasionally found on Peromyscus. Three flea species were found on grasshopper mice, most of which $(18 / 20 ; 90.0 \%)$ were Pleochaetis exilis, although an $O$. sexdentatus (the woodrat flea) and an $O$. montana (the rock squirrel flea) were also identified. Many fleas were collected from cottontails, with $75.1 \%$ of these being identified as Cediopsylla inaequalis (212/281; 75.4\%).

\section{Fleas in woodrat nests}

One hundred twenty-seven fleas were collected from 17 of the $20(85 \%)$ woodrat nests inspected. The number of fleas collected from a nest varied from zero to 29 . The most common flea species collected from the woodrat nests were Anomiopsyllus nudatus (71/127, 56\%) and Megarthroglossus divisus $(48 / 127,38 \%)$, both of which belong to genera known to be found commonly in nests (Holland 1985). Only five (4\%) fleas of $O$. sexdentatus, the most common species on woodrat hosts, were found in woodrat nests. Three more flea species were represented by single individuals: Amaradix euphorbia, Epitidea wemmani, and Malaraeus sinomus.

\section{Y. pestis DNA in fleas}

A total of 3156 fleas of 23 species were screened for the pla gene. Nine fleas collected from six southern plains woodrats, a white-throated woodrat, and a rock squirrel were PCR positive. Plague-positive fleas found on the woodrats belonged to the species $O$. sexdentatus (6) and O. neotomae (2), while positive fleas from the rock squirrel were $O$. montana (2). No positive flea was found among the 127 fleas collected from 17 woodrat nests.

\section{Y. pestis antibody in mammals}

Serological screening of 1798 blood samples resulted in the detection of 15 animals with $Y$. pestis antibody titer $\geq 1: 32(0.8 \%)$ by PHA. The positive sera were obtained from 11 individual small mammals of 7 species, including $\mathrm{N}$. $\mathrm{mi}$ cropus (1), O. leucogaster (1), P. leucopus (4), P. maniculatus (2), P. truei (1), O. variegatus (1), and S. audubonii (1). Individuals testing seropositive at multiple time points were O. variegatus (caught thrice in May 2003, June 2003, and June 2004) and O. leucogaster (caught twice in July 2003 and September 2003). One rock squirrel remained seropositive for at least a 13-month period. It had a high antibody titer against $Y$. pestis (1:8192) when it was first captured in May 2003. Next month (June 2003), this animal still had a high antibody titer (1:4096). The last time this squirrel was collected in June 2004, its antibody titer was still positive, but had decreased to 1:64. One grasshopper mouse remained seropositive for at least 2 months. It had an antibody titer of 1:4096 in July 2003 and 1:256 in September 2003.

\section{Y. pestis in tissues and fleas}

$Y$. pestis antigen-positive tissues were identified by DFA in carcasses of four dead animals found near trapping sites. Three plague-positive dead animals belonged to woodrat species $N$. albigula (2) and N. micropus (1), and one to S. audubonii. Although antigen detection produced positive laboratory 
results, culture attempts failed to recover viable $Y$. pestis organisms. A culture of $Y$. pestis, confirmed by bacteriophage lysis, was obtained from one of the PCR-positive fleas $(O$. sexdentatus) originating from a dead woodrat (N. micropus).

Die-offs, occupancy status of woodrat nests, and the spatial relationship to plague-positive samples

Site 1. During the period of observation between November 2002 and April 2003, 93\% of the 60 TS within both study sites were occupied (Figs. 1 and 2). The number of TS with no rodents captured during this period varied from 4 to 7 (7-12\%) and these vacant TS were scattered across the study site without clear clustering. The first incidence of plaguerelated disappearance of woodrats from some TS was observed in March 2003, when fleas from two woodrats collected close to each other in the north-eastern part of the site (Fig. 1; TS 24 and 26) were found to be PCR positive. In May 2012, two more positive fleas were found from a woodrat captured from one of these nests and from a neighboring nest (Fig. 1; TS 24 and 23). In addition, a woodrat from one of these nests (Fig. 1; TS 23) was serologically positive.

Beginning in June 2003, nearly half (48\%) of the nests within the site were found free of woodrats, with the concentration of empty nests being particularly abundant in the north-eastern and eastern parts of the site (Figs. 1 and 3; TS
16-21 and 42-49). Two dead woodrats were found within these TS (Figs. 1 and 3; TS 45 and 46) and both carcasses tested positive by DFA. Only three woodrats were captured in the north-eastern part of study site 1 , but one of those was serologically positive. By July 2003, the area that was completely devoid of woodrats had extended and covered 39 empty nests within study site 1 . The same situation remained in September 2003. During the period from July to September in 2003, two serologically positive grasshopper mice and a positive flea from a woodrat were detected close to the die-off area (Figs. 1 and 3; TS 15, 16, and 53).

In October 2003, most of the woodrat nests remained empty ( 38 of $60,63 \%$ ), but three nests, which were deserted during the summer, had been reoccupied. In November and December 2003, the area of woodrat die-off extended to the southern part of the site (Figs. 1 and 3; TS 1 to 10). Overall, 42 of 60 nests $(70 \%)$ were unoccupied. Two carcasses of woodrats, which tested positive for $Y$. pestis antigen, were found near TS 50 and 51 in the western part of the site, the same nests which were recolonized in October (2003). By early spring of the next year (March and April 2004), most of the site remained devoid of woodrats; 44 of $60(73 \%)$ nests were empty. During the summer of 2004, several nests were reoccupied; woodrats were found in 27 (45\%) TS in MayJune and in $30(50 \%)$ TS in July-September. Two clusters of TS in the central part (Figs. 1 and 3; TS 12-14 and 28-31) of
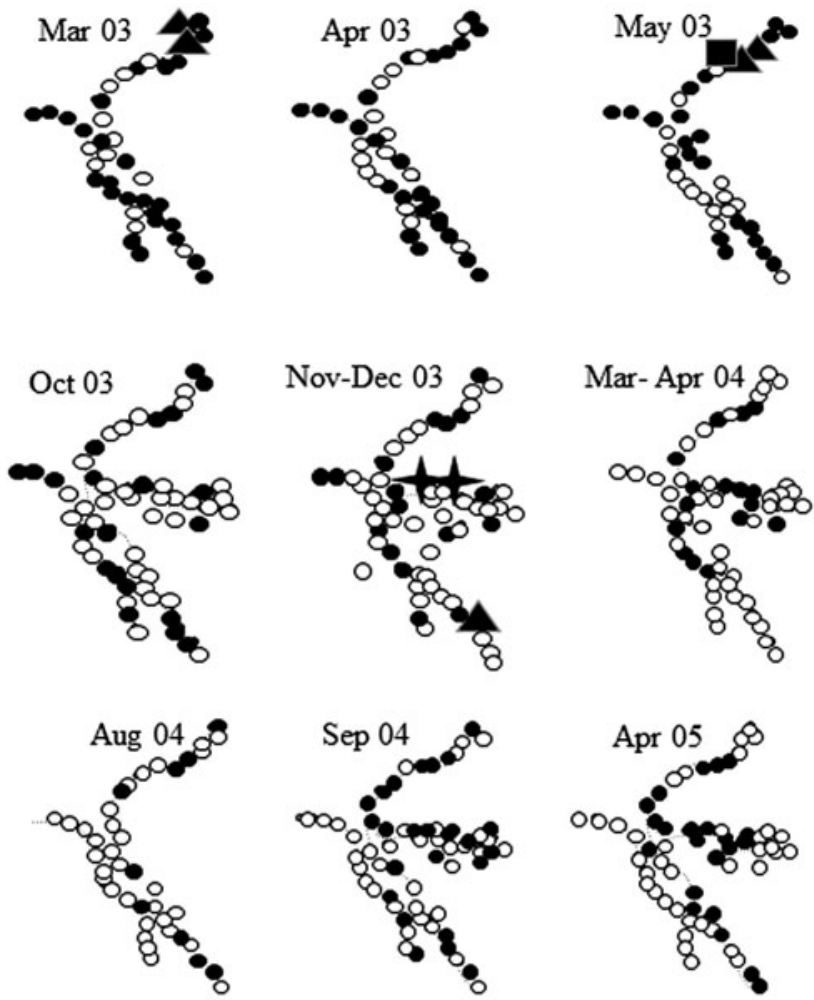
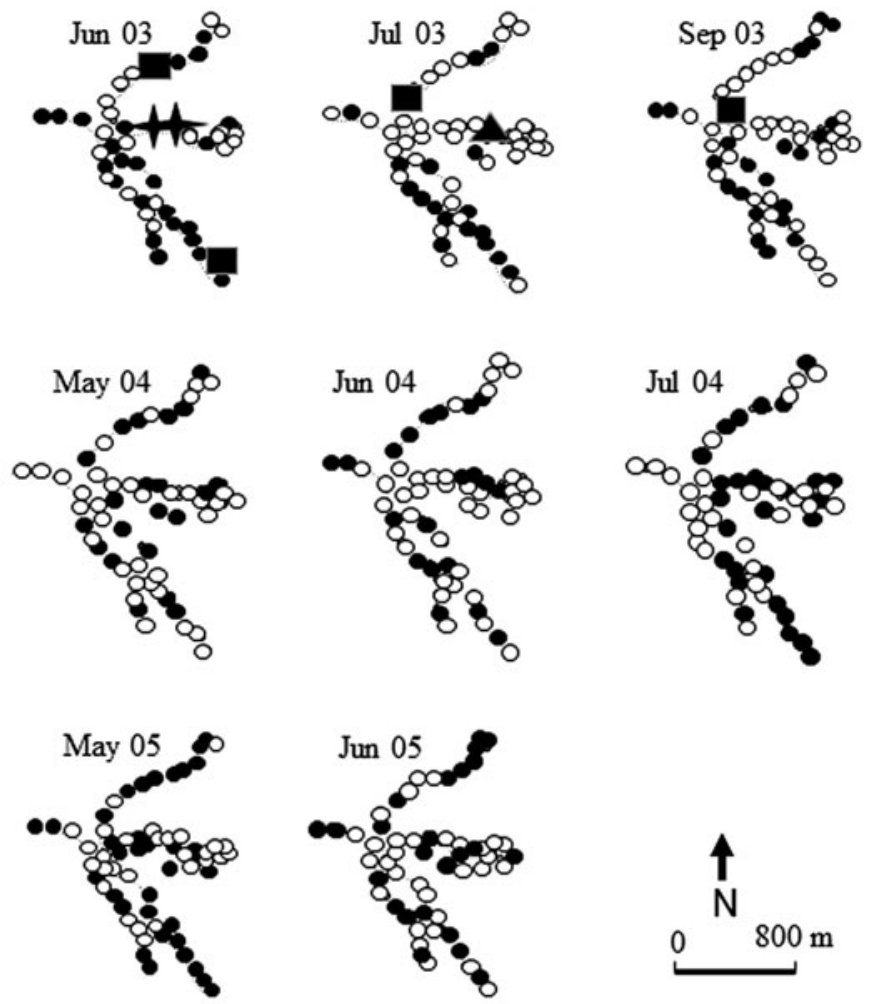

occupied woodrat nest $\bigcirc$ abandoned woodrat nest

Y. pestis-positive flea

Y-pestis antibody positive animals

dead animals with $Y$-pestis antigen positive tissues

FIG. 1. Rodent die-offs, occupancy status of woodrat nests, and the spatial relationship to plague-positive samples within study site 1 . 

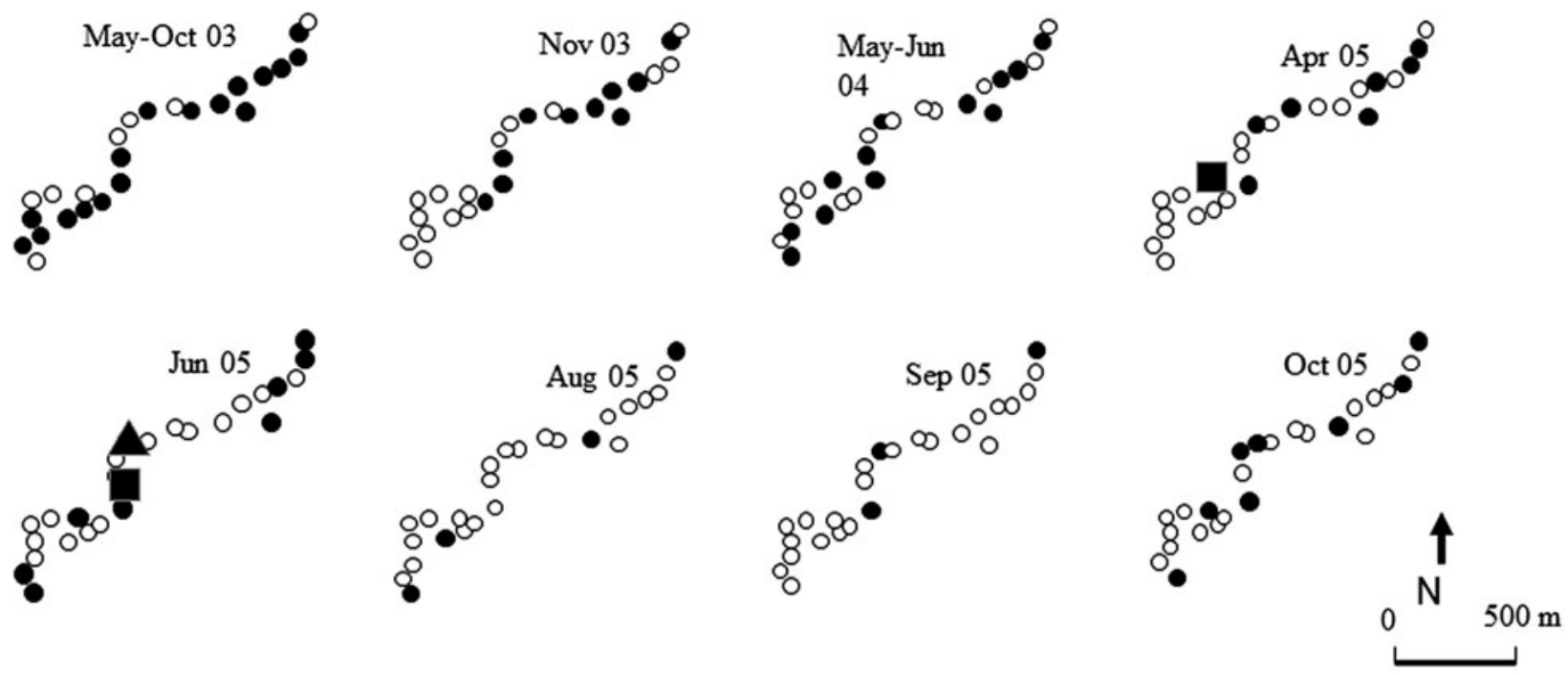

occupied woodrat nest $\bigcirc$ abandoned woodrat nest

Y. pestis-positive flea

Y-pestis antibody positive animals

$\mathcal{f}$ dead animals with $Y$-pestis antigen positive tissues

FIG. 2. Rodent die-offs, occupancy status of woodrat nests, and the spatial relationship to plague-positive samples within the study site 2 .
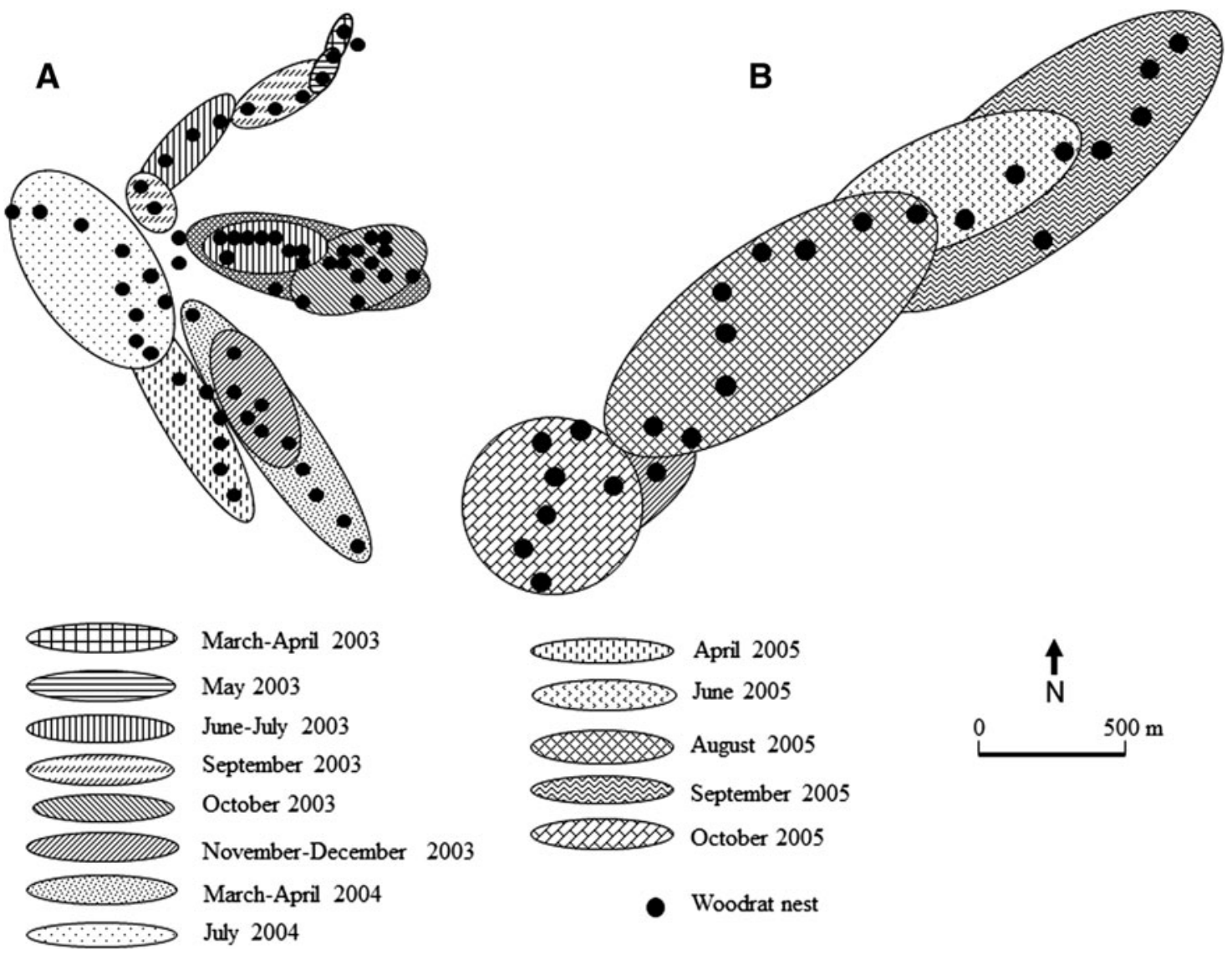

FIG. 3. The territories of both the study sites 1 (A) and 2 (B) were completely covered by small local die-offs of woodrats during the period from March 2003 through April 2005. Numbered circles correspond to specific trap stations. 
the site remained rat free. Next spring, all nests located in the south-eastern part of the site (Figs. 1 and 3; TS 27-40) were found devoid of woodrats. In May-June 2005, some nests located in different parts of area were reoccupied. In April 2005, 36 of 60 nests $(62 \%)$ were vacant; in May-June of the same year only $23(38 \%)$ remained vacant.

Site 2. During the period from May to October 2003, 13 of $25(52 \%)$ TS were occupied and all vacant nests were distributed across the site with no clusters or trends noted. In November 2003, a cluster of nine nests (Fig. 2; TS 5-5 to 510) were found free of rats, although no plague-positive specimens were identified. During 2004, some of these same nests were recolonized, but by April 2005, the reoccupied nests were again found empty and a plague-positive animal was found in the area (Fig. 2; TS 5-2). In the summer of 2005, woodrats disappeared from 6 nests in the central part of the site (TS 4-5 to 4-10) in June and from 10 nests in August (TS 4-1 to 4-7 and 5-1 to 5-3) (Fig. 2). A positive animal was also found in this area. At the same time, two nests (Fig. 2; TS 5-8 and 5-9) in the very southern part had been reoccupied. By September 2005, only three of $25(12 \%)$ nests were occupied. In October 2005 (the last time point of the study) four nests had been recolonized by woodrats.

\section{Discussion}

The purpose of this study was to better define woodrat population dynamics that might contribute to the long-term persistence of plague activity within small-scale ecosystems. Previous reports were based on a single time frame, descriptions of individual human plague case investigations and associated small mammal and flea observations (Perlman et al. 2003, Colman et al. 2009). In this study, data were collected for key parameters of the plague system (rodent population and flea ectoparasite dynamics, ectoparasite population dynamics in nests, and ectoparasite and rodent infection rates) in a systematic long-term study. Longitudinal studies of zoonotic pathogens and their hosts using markrelease-recapture techniques are widely regarded as indispensable approaches for understanding population and temporal dynamics of zoonotic infections.

Just how plague manages to persist over long periods (years to decades) of time in a given ecosystem despite massive die-offs of some host species, and how it persists through lengthy quiescent periods, is poorly understood and worthy of investigation. Generally speaking, the main competing hypotheses to explain how plague can survive during epizootics have been summarized in various reviews as follows: (1) resistant rodent species remain chronically infected with plague (Kartman et al. 1964, Poland and Barnes 1979); (2) Y. pestis can persist in a chronic form (e.g., in granulomas) being activated or disseminated within individuals by a change of immune status or physiologic condition of the animal, thus allowing infection of feeding flea vectors (Gage and Kosoy 2006); 3) low virulent variants of $Y$. pestis can circulate among rodent hosts and be transformed into highly virulent variants under specific environmental conditions (Domaradsky 1999); (4) the pathogen can be maintained in the guts of fleas for periods of time sufficient for bridging periods of epizootics in mammals; (5) a high diversity rodent community is required for persistence of plague by switching host species; (6) a population of highly susceptible hosts occurs over a sufficiently large area that at least some subpopulations within a larger metapopulation survive and continue to reproduce and later are available to be infected; and (7) $Y$. pestis can persist in soil or in nest material within rodent burrows possibly in dormant, uncultivable form or in association with soil protozoa or nematodes (Domaradsky 1999, Gage and Kosoy 2006).

We demonstrated that the transmission of a highly virulent strain of $Y$. pestis between rodents, indeed, persisted over a multiyear study period within the relatively small study area. This may not be the situation when plague survives in a "cryptic" form for years or decades without a visible manifestation.

Our study also has not identified any new evidence that the rodent species studied are fully or partially resistant to plague. The mere presence of some small rodents (Peromyscus and Dipodomys species) in the vicinity of woodrat nests affected by plague epizootics is not sufficient evidence to conclude that these animals contributed to the maintenance of plague circulation after a die-off of woodrats. These rodents had very low numbers of fleas on them, reducing their chance of exposure and possibly explaining their survival for a prolonged period of time after visiting, or cohabitating in, die-off areas. More likely, these rodents did not even go inside woodrat nests.

Our data do not support the hypothesis that maintenance of plague in this area involves the participation of multiple rodent species. Nonetheless, our data cannot refute the hypothesis that high diversity in a rodent community is a crucial factor for persistence of the infection by switching host species. Although the number of rodent species recorded at least once within the study area was quite high (14 species), overall this rodent community was characterized by the strong dominance of woodrats, particularly by one woodrat species, $N$. micropus. Although rock squirrels (O. variegatus) are often recognized as principal hosts of plague and the major mammalian source of human infection in some areas of the U.S. Southwest, and are widespread across New Mexico (including Santa Fe County), they were few in number in this particular area and were not trapped during our study.

Deer mice were found (42 of 1194 small mammal individuals) during this study, but the observed low level of flea infestation suggests their role as active players in plague transmission in this ecological system is minimal. Detection of $Y$. pestis-antibodies in the blood of mice (Peromyscus sp. and Onychomys sp.) can serve as a good demonstration of potential exposure of these mice to the plague pathogen; however, it does not present sufficient evidence of their significant involvement in the transmission cycle. The range of rodent species that can produce $Y$. pestis bacteremia at levels sufficient for flea transmission is likely narrow compared to those rodent species that can develop $Y$. pestis-specific antibody (Gage and Kosoy 2006).

Overall, our data suggest that the populations of woodrats contribute substantially to the continuous transmission of plague and allow its persistence in this ecosystem, regardless of observed die-offs among woodrats. Two important observations were made during the study period of 2.5 years. First, all parts of the investigated area were subjected to epizootics followed by a local disappearance of woodrats (Fig. 4). Second, despite the active die-offs, some woodrats 


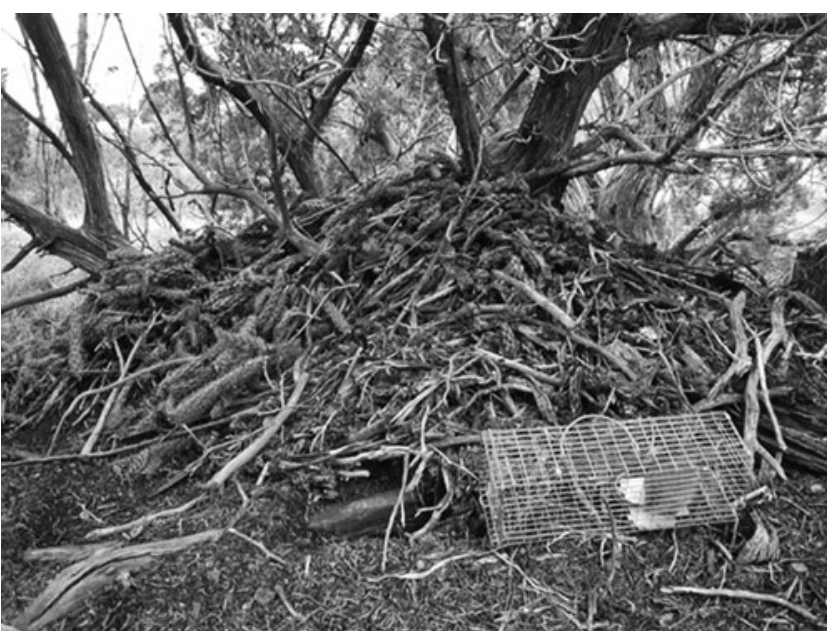

FIG. 4. Woodrat den with a southern plains woodrat inside the trap at the entrance to the den. For scale, the trap shown is 16 inches long $(40.6 \mathrm{~cm})$. Photo by Michael Kosoy.

always were present within the relatively limited endemic territory and apparently were never exposed to plague (negative antibody titers). The number of nests occupied by woodrats during this period varied from $18(30 \%)$ to 56 (93\%) of the monitored 60 TS within site 1 and from 4 (16\%) to $17(68 \%)$ of the 25 TS within site 2 (Fig. 3).

One plausible hypothesis for explaining the persistence of plague is the long-term survival of $Y$. pestis in the guts of infected fleas. Apparently, from our observations, some woodrats died after reoccupying the nests emptied by recent plague epizootics. For example, at site 1, two plague-positive carcasses were found in November 2003 near nests that were recolonized just a month earlier after a die-off was observed there in the summer months. It would be logical to expect that infectious fleas survived within the nest and could contribute to the rat infection. Athough we cannot exclude the possibility that the woodrats died after exposure to infected substrate within the nest, we can perhaps assume the survival of infected fleas within the abandoned nests for a period of weeks to a few months (Gage and Kosoy 2005). However, the length of survival of infectious fleas probably did not exceed this period since several recolonizations of the nests by woodrats after 3-4 months or more did not lead to the death of newcomers.

Likely, a successful recolonization of nests by woodrats could not happen if infectious fleas survive for a longer period. Our study demonstrated that the species composition of fleas in the investigated nests was drastically different from those collected on hosts. While $O$. sexdentatus was the most common flea species $(68.4 \% ; 1341 / 1961)$ on hosts, only $3.9 \%$ $(5 / 127)$ of the fleas collected from woodrat nests and burrows belonged to this species. The two genera most commonly recovered from the nests and burrows were Anomiopsyllus and Megarthroglossus, both of which are known to be "nest fleas" that spend the majority of their time in this habitat rather than on their hosts as does O. sexdentatus (Stark 1970).

The question of how plague can be maintained within a relatively small area is still open to debate, but our longitudinal study has provided insights that support the view that a complex of woodrat nests can support continuous small-scale plague die-offs within this endemic territory with little, or minimal, contributions from other species. The slow movement of plague between patches can be explained by the strong territoriality of woodrats.

Our observations demonstrated many recaptures of the same woodrats at the same dens during several years, suggesting that individual woodrats may occupy one den throughout their entire adult life. Other studies have shown that the availability of a nest in close proximity to another den has not resulted in exchange of the occupants (Braun and Mares 1989). Most of the woodrat dens in this particular study area are quite large (Fig. 4) and construction of such dens is undoubtedly time and labor intensive. Radiocarbon dating indicated that woodrat nests can be preserved up to 40,000 years and although woodrats seem to abandon their middens (an archeological term meaning garbage pile), after a few years or decades they can build new middens on top of old ones ( Jackson, personal communication, Jackson et al. 2005). Since dens are continuously used by many generations of woodrats, it is very unlikely their houses are voluntarily deserted by their occupants.

Local die-offs of woodrats can serve as an indicator of active plague epizootics. This assumption is based on several points: (1) populations of woodrats are relatively stable and not subjected to dramatic fluctuations observed in other small rodents (e.g., Peromyscus mice); (2) deaths from other sources, for example, from a predator, usually do not occur simultaneously in many neighboring nests; (3) the plague pathogen was detected in dead woodrats found close to the inactive nests; and (4) no other pathogen has been proven to cause massive die-offs of woodrats.

Spatial structure of rodent populations has been recognized as an important factor for the invasion and spread of infectious agents (Rotshild 1975, Keeling 1999, Wilschut et al. 2015). Analyzing the distribution of the burrows of great gerbils (Rhombomys opimus) in Kazakhstan, Wilschut et al. (2015) concluded that spatial clustering of occupied burrows should be considered to assess its significance for plague transmission. In another study, an investigation of plague outbreaks in prairie dog (Cynomys ludovicianus) populations, the authors argued that plague can persist in the highly susceptible hosts because their movement is very constrained (Salkeld et al. 2010).

Theoretical modeling by Caraco et al. (2001) clearly demonstrated that the spread of vector-borne infection is particularly low when host spatial heterogeneity (small neighborhood size and clumping) limits the vector's advance. The conservative territoriality of both $N$. albigula and $N$. micropus (Macedo and Mares 1989, Braun and Mares 1989) also may have significant implication for persistence of plague in their populations. An important parameter for such a model is survival time of the pathogen in the "nest environment." This time period should be long enough (months) to support maintenance of plague in the area, but not too extensive (years) that recolonization of the nests by new naive animals is prohibited. In the latter case, migrant individuals would be quickly killed by bites of infectious fleas or from exposure to infected nest substrate ("hot nest").

Ecological analysis can provide enough insights to explain long-term maintenance of plague in some relatively small areas characterized by specific environmental conditions, socalled "natural foci of plague." Because the micro-ecosystems of such foci may vary widely, further longitudinal studies are badly needed. Such studies also can provide information that 
can be helpful in designing improved prevention and control measures that can be tailored to specific locations.

\section{Acknowledgments}

We are grateful to all people who took an active participation in the field work, particularly to Nelson Powers (postmortem), Ted Brown, Kevin Castle, Christina Morway, David Wagner, and Rebecca Colman. We thank Christina Morway for her assistance in the laboratory work.

\section{Author Disclosure Statement}

No competing financial interests exist.

\section{References}

Braun JK, Mares MA. Neotoma micropus. Mammalian Species 1989; 330:1-9.

Brinkerhoff RJ, Collinge SK, Ray C, Gage KL. Rodent and flea abundance fail to predict a plague epizootic in black-tailed prairie dogs. Vector Borne Zoonotic Dis 2010; 10:47-52.

Caraco T, Duryea M, Glavanakov S. Host spatial heterogeneity and the spread of vector-borne infection. Theor Popul Biol 2001; 59:185-206.

Chu M. Laboratory Manual of Plague Diagnostic Tests. Atlanta, GA: CDC-WHO, 2000:129.

Colman R, Vogler A, Lowell J, Gage K, et al. Fine-scale identification of the most likely source of a human plague infection. Emerg Infect Dis 2009; 15:1623-1625.

Davis R, Smith R, Madon M, Sitko-Cleugh E. Flea, rodent, plague ecology at Chuchupate Campground, Ventura County, California. J Vector Ecol 2002; 27:107-127.

Domaradsky IV. Is plague a "protonosis"? (The role of protoaoza in plague epizootology) Med Parazitol (Moscow) 1999; 2:10-13.

Fenyuk BK. Ecological factors of plague focality. Zoologicheckiy Zhurnal (Leningrad) 1940; 19:349-351.

Friggens MM, Parmenter RR, Boyden M, Ford PL, et al. Flea abundance, diversity, and plague in Gunnison's prairie dogs (Cynomys gunnisoni) and their burrows in montane grasslands in northern New Mexico. J Wildlife Dis 2010; 46:356-367.

Furman DP, Catts EP. Manual of Medical Entomology. New York: Cambridge Univ Press, 1982:207.

Gage K, Kosoy M. Natural history of plague: Perspectives from more than a century of research. Annu Rev Entomol 2005; 50:505-528.

Gage K, Kosoy M. Recent trends in plague ecology. In: Roelle JE, Miller BJ, Godbey JL, Biggins DE, eds. Recovery of the Black-Footed Ferret: Progress and Continuing Challenges. Reston, Virginia: U.S. Department of the Interior U.S. Geological Survey, 2006:213-231.

Goldenberg M, Quan S, Hudson B. The detection of unapparent infection with Pasteurella pestis in a Microtus californicus population in the San Francisco Bay area. Zoonoses Res 1964; 3:1-13.

Holland GP. The fleas of Canada, Alaska, and Greenland (Siphonaptera). Memoirs of the Entomological Society of Canada. No. 130. Ottawa: Entomological Society of Canada, 1985:631.

Hopkins GHE, Rothschild M. An Illustrated Catalogue of the Rothschild Collection of Fleas (Siphonaptera) in the British
Museum. London: University Printing House Cambridge, 1971:vol. 5.

Hubbard CA. Fleas of Western North America. Ames, IA: The Iowa State College Press, 1947:533.

Jackson ST, Betancourt JL, Lyford ME, Gray ST, et al. A 40,000-year woodrat-midden record of vegetational and biogeographical dynamics in north-eastern Utah. J Biogeogr 2005; 32:1085-1106.

Kartman L, Quan S, Stark H. Ecological studies of wild rodent plague in the San Francisco Bay area of California. Zoonoses Res 1964; 1:99-119.

Keeling MJ. The effects of local spatial structure on epidemiological invasions. Proc Biol Sci 1999; 266:859-867.

Lang J, Wills W. Ecology of sylvatic plague in the San Jacinto Mountains of Southern California. Bull Soc Vector Ecol 1991; 16:183-199.

Macedo RH, Mares MA. Neotoma albigula. Mammalian Species 1989; 310:1-7.

Morway C, Kosoy M, Eisen R, Montenieri J, et al. A longitudinal study of Bartonella infection in populations of woodrats and their fleas. J Vector Ecol 2008; 33:353-364.

Perlman D, Primas R, Raucher B, et al. Imported plague. New York, 2002. Morb Mortal Wkly Rep 2003: 52:725-728.

Poland J, Barnes A. Plague. In: Steele JH, Stoenner H, Kaplan $\mathrm{W}$, eds. CRC Handbook Series in Zoonoses, Section A: Bacterial, Rickettsial, and Mycotic Diseases. Boca Raton, Florida: CRC Press, Inc., 1979, vol. 1:515-597.

Rall YM. Natural Focality and Epizootiology of Plague. Moscow: Medgiz, 1965:338.

Rotshild EV. Analysis of the spatial structure of a natural focus of plague. Med Parazitol (Moscow) 1975; 44:427-433.

Salkeld DJ, Salathé M, Stapp P, Jones JH. Plague outbreaks in prairie dog populations explained by percolation thresholds of alternate host abundance. Proc Natl Acad Sci 2010; 107: 14247-14250.

Salkeld DJ, Stapp P. No evidence of deer mouse involvement in plague (Yersinia pestis) epizootics in prairie dogs. Vector Borne Zoonotic Dis 2008; 8:331-337.

Stark HE. A Revision of the Flea Genus Thrassis Jordan 1933 (Siphonaptera: Ceratophyllidae) With Observations on Ecology and Relationship to Plague. Berkeley and Los Angeles: University of California Press, 1970:184.

Stevenson H, Bai Y, Kosoy M, Montenieri J, et al. Detection of novel Bartonella strains and Yersinia pestis in prairie dogs and their fleas Siphonaptera: Ceratophyllidae and Pulicidae) using multiplex polymerase chain reaction. J Med Entomol 2003; 40:329-337.

Wilschut LI, Laudisoit A, Hughes NK, Addink EA, et al. Spatial distribution patterns of plague hosts: Point pattern analysis of the burrows of great gerbils in Kazakhstan. J Biogeogr 2015; 42:1281-1292.

\section{Address correspondence to: Michael Kosoy Division of Vector-Borne Diseases Centers for Disease Control and Prevention Fort Collins, CO 80521}

E-mail: mck3@cdc.gov 